This document is the accepted manuscript version of the following article:

Fischer, M., \& Sciarini, P. (2013). Europeanization and the inclusive strategies of executive actors. Journal of European Public Policy, 20(10), 1482-1498.

https://doi.org/10.1080/13501763.2013.781800

\title{
Europeanization and the inclusive strategies of executive actors
}

Manuel Fischer and Pascal Sciarini

ABSTRACT In Europeanized policy domains, executive actors are considered especially powerful because they are directly responsible for the international negotiations. However, in order to avoid failing in the ratification process, they are also highly dependent on the support of domestic, non-state actors. We argue that in Europeanized decision-making processes, state actors are not passively lobbied, but actively seek collaboration with - and support from domestic actors. We apply stochastic actor-based modeling for network dynamics to collaboration data on two successive bilateral agreements on the free movement of persons between Switzerland and the European Union (EU). Results confirm our hypotheses that state actors are not passively lobbied, but actively look for collaboration with other actors, and especially with potential veto players and euro-skeptical actors from both the conservative Right and the Left.

KEY WORDS Collaboration network; Europeanization; inclusive strategies; state executives; stochastic actor-oriented modeling. 


\section{INTRODUCTION}

One of the major findings of the Europeanization literature is that state executives (the national government and its administration) are strengthened in internationalized policy domains because they are responsible for international negotiations (Moravcsik 1998, Goetz and Meyer-Sahling 2008). According to this view, the empowerment of state executives stems from institutional and informational advantages gained from their presence at the international negotiation table. For the same reason, state executives become the main targets of collaboration attempts from domestic, non-state actors.

In this paper, we depart from this standard view and argue that in Europeanized decisionmaking processes, state actors are not passively lobbied, but, rather, actively seek collaboration with - and support from - domestic, non-state actors. Even if internationalization increases their power, state executives always face the risk of failure in the ratification phase. To reduce this risk and to reach broad support for their foreign policy proposal, they may decide to inform, consult and/or integrate domestic actors in the decisionmaking process. This inclusive strategy leads state executives to initiate collaboration with domestic actors in general, and with potential veto-players in particular.

Against this background, the purpose of our paper is to analyze if and how the inclusive strategy of national state executives influences the collaboration network in a Europeanized policy domain. To that end, we rely on a case study of the two bilateral agreements on the free movement of persons negotiated between Switzerland and the European Union (EU) from 1993-2000 and 2002-2005, respectively to which we apply a stochastic actor-oriented model for network dynamics (SAOM, Snijders et al. 2010). Such models are relatively new to political science, but they allow for potentially important empirical insights into policy networks and processes of policy-making (see Berardo and Scholz 2010, Fischer et al. 2012, Lubell et al. 2012). They predict network changes both endogenously, as a function of the current network structure, and exogenously, as a function of actors' characteristics and the 
characteristics of pairs of actors. The analysis on the micro level allows for the study of how actors' strategies influence networks over time.

The remainder of this paper is structured as follows. Section two elaborates on the strategies of state actors in Europeanized policy domains. Section three presents the bilateral treaties on the free movement of persons. The longitudinal dataset and the stochastic actor-oriented model are presented in section four. Empirical results are discussed in section five and section six presents the conclusions of our study.

\section{ANALYTICAL FRAMEWORK}

\section{Collaboration in policy networks}

In modern policy-making, different collective actors such as political parties, interest groups, state executives, administrative agencies, regional units, and experts participate in different venues of the decision-making process and collaborate in so-called policy networks (Knoke et al. 1996, Börzel 1998, Kriesi et al. 2006a, Henry 2011). Collaboration is a prerequisite for coalition building, as no single actor has sufficient resources to influence political decisionmaking unilaterally (Sabatier and Weible 2007, Henry 2011). Through collaboration ties, actors exchange information and resources, coordinate their activities, or negotiate over policy proposals (Weible and Sabatier 2005: 182). It should be noted that in this study, we rely on a broad and neutral definition of collaboration. The fact that political actors collaborate closely does not necessarily mean that they agree on the substantive policy issue at stake. In many cases, actors negotiate precisely because they have opposing views and are attempting to find a compromise. ${ }^{1}$ This holds especially in "corporatist-like" countries such as Switzerland and other small European countries that have long-lasting traditions of negotiation among nonstate actors, and between non-state actors and state executives (e.g. Katzenstein 1985).

Actors in policy networks cultivate new relationships and drop old ones in order to increase the likelihood of favorable outcomes. They are constrained by formal authority and existing 
relations, costs and uncertainties, as well as limitations imposed by cognitive capacities (Scholz et al. 2008, Snijders et al. 2010). In the following section, we discuss how state actors' strategic behavior influences the policy network in Europeanized policy domains.

\section{Europeanization and the strategic behavior of state actors}

As compared to domestic decision-making processes, the most important specificity of Europeanized processes is the existence of international negotiations, which shifts the center of gravity away from the domestic level (Moravcsik 1998). Taking place at the beginning of the process, these negotiations substantially influence the content of the act. The government and its administration represent the state in the international arena in general and in international negotiations in particular. As a result, they enjoy a strategic position: they set the domestic political agenda, they have privileged access to information, and together with their negotiating partners, they define the content of international treaties. Along the same lines, Putnam's (1988) work on the "two-level-game" argues that the presence of international negotiations reinforces state executives that can take advantage of their presence at both the international and domestic levels, and benefit from a reinforced autonomy with regard to domestic actors, including the legislative body. Behaving strategically, state executives can to some extent "manipulate" the domestic agenda, and they can also use their external leverage to impose domestic reforms. By tying their hands with an international agreement, state executives may increase their strength in the domestic arena.

By contrast, domestic actors such as national parliaments and non-state actors are unable to initiate international treaties, suffer from lack of information, and cannot directly influence the content of treaties. In addition, the strong "take-it-or-leave-it" character of agreements concluded at the international level reduces the space for amendments in the ratification phase. Domestic actors can accept or reject international treaties, but they can hardly modify them, since any amendment would send their government back to the negotiation table, and 
possibly jeopardize the whole process (in case the negotiation partner opposes a renegotiation). Earlier studies in Switzerland and abroad provide consistent empirical evidence to support the view that Europeanization strengthens state executives and weakens both the legislative body and non-state actors (Sciarini et al. 2004, Fischer 2005, Goetz and MeyerSahling 2008). ${ }^{2}$

However, internationalized or Europeanized decision-making processes do not grant advantages only to state executives. They also come with constraints. Any agreement negotiated on the international level must still be accepted domestically, and domestic actors have the possibility to turn down the agreement in the ratification phase. If they believe that they would be better off with no international treaty rather than the one negotiated by their government, they may well end up rejecting it. Certainly, state executives are aware of this risk: they know that they need to go through the ratification process and gain domestic support for the international agreement. To avoid ratification failure, state executives must collaborate with domestic actors, most importantly potential veto-players, and integrate them into the decision-making process. In summary, we argue that the effects of an international negotiation on state executives are ambivalent. On the one hand, it increases their autonomy, but on the other, it renders them more dependent on the support of domestic actors.

Thus, instead of being passively lobbied by domestic non-state actors attempting to influence the content of an international treaty, we argue that state executives must actively look for support. Such collaborative efforts may, for example, take the form of information sessions, informal and formal consultation ${ }^{3}$ (Sciarini et al. 2004, Fischer 2005), or the elaboration of compensation mechanisms, or so-called "side payments" (Fischer 2002, 2003). These collaboration efforts by state executives do not only take place in the aftermath of international talks. Anticipating opposition in the ratification phase, state actors may already decide to integrate domestic non-state actors before and during the international negotiations. Given that formal consultation procedures are not well-suited for coping with the rapid and 
discontinuous rhythm of international talks, state actors may rely on more informal and selective forms of consultation (Mach et al. 2003, Sciarini et al. 2004). From this, we derive our first hypothesis:

H1: In Europeanized decision-making processes, state executives have a strong tendency to collaborate with domestic non-state actors.

Going one step further, we hypothesize about the specific actors or actor groups that may be the target of state actors' collaboration efforts. Domestic non-state actors are not all equally susceptible to threatening international treaties. State executives are likely to collaborate mainly with non-state actors that are able to veto the domestic decision-making process. This ability, in turn, depends on a country's institutional design and, more specifically, on the number of institutional veto-points. A political system with a high number of veto-points grants opponents several opportunities to oppose political changes (Immergut 1990). A similar argument is put forward in the Europeanization literature (e.g. Haverland 2000): the higher the number of veto points in a system, the higher the likelihood that domestic actors are able to block change. As a matter of fact, international treaties have to be agreed upon at various stages of the decision-making process that all offer chances to oppose a given reform. In Switzerland, there are two major veto-points during the ratification process, i.e. the bicameral parliament and the optional referendum applying to international treaties. In such a context, state executives are likely to be especially careful. More specifically, if they want to reduce the risk of ratification failure, they have to integrate actors from which they anticipate opposition. In Switzerland as elsewhere, two groups of actors are known to be skeptical towards European integration: actors from the populist, conservative Right who are culturally more protectionist and actors from the Left (i.e. left-wing parties and trade unions), who are known to be socially and economically protectionist ("inverted U-curve of euroscepticism", 
see Hooghe et al. 2002, Kriesi et al. 2006b). Both types of actors are potentially able to activate veto-points. ${ }^{4}$ We should therefore witness a deliberate attempt by state actors to collaborate with actors from the conservative Right and from the Left in order to integrate them into the decision-making process and, possibly, to overcome their opposition.

H2: In Europeanized decision-making processes, state executives have a strong tendency to collaborate with potential veto players from both the Left and the conservative Right.

\section{THE CASE OF THE FREE MOVEMENT OF PERSONS}

After the rejection of the adhesion to the European Economic Area (EEA) by the Swiss people in 1992, the Swiss government committed itself to negotiating bilaterally with the EU on issues of common interest. This resulted in the conclusion of two sets of bilateral treaties (seven agreements in 1998, and nine in 2004). The free movement of persons between member states is a major achievement of the $\mathrm{EU}$ and a cornerstone of the 'acquis communautaire'. Similarly, the agreement of the free movement of persons is one of the most important bilateral treaties concluded between Switzerland and the EU (Dupont et al. 2001). Through the first agreement concluded in 1998, the strict quota system of immigration and residence permits for EU citizens was abolished and citizens of Switzerland and the EU were allowed to settle and work in the EU or in Switzerland, respectively. In Switzerland, the agreement was accompanied by so-called flanking measures in order to protect Swiss workers against social and wage dumping (Fischer 2002, Fischer et al. 2002). An overwhelming majority of the Swiss population accepted a referendum on the first package of bilateral agreements with the EU in 2000, which was enforced in 2002. Still, the fact that the Swiss government was able to reach across-the-board support for the bilateral agreements stood in sharp contrast with the case of the EEA in which it suffered a major popular defeat. In particular, while the free movement of persons had been a major reason for rejection of the 
EEA in 1992 (Kriesi et al. 1993, Sciarini and Listhaug 1997) it was widely supported eight years later.

In 2002, 10 Eastern and Southeastern European countries joined the EU. This required new negotiations of the agreement on the free movement of persons between Switzerland and the EU (Dupont and Sciarini 2006). Additionally, the flanking measures were extended, including the introduction of checks by labor inspectors, stricter reporting requirements for foreign companies in the deployment of workers, and the facilitation of the extension of collective agreements. After an intense campaign, $56 \%$ of voters accepted the extension of the free movement of persons to the new EU member countries in 2005.

\section{DATA AND METHODS}

\section{Data}

Data on policy networks comparable over time is rare, not least of all because gathering the same data at various points in time is resource-demanding (Scholz et al. 2008: 397). In that sense, the data at our disposal is exceptional. The first data-set covers the first bilateral agreement and the second covers its extension to the new member states. Both were gathered through face-to-face interviews in 2001/2002 (see Fischer et al. 2002, Sciarini et al. 2004, Fischer 2005) and 2008 (Fischer 2012).

In line with a widespread view (e.g. Knoke et al. 1996: 7), we believe that collective actors, rather than individuals, stand at the forefront of today's politics. To identify the main actors involved in each of the two decision-making processes, we used the classic combination of positional, decisional, and reputational approaches (see e.g. Knoke 1993: 30). First, following the decisional approach, we identified the actors that took part in the different venues (e.g. expert committees, consultation procedure, parliamentary committees, etc.) of the two decision-making processes. To this list, we added the actors holding an overall strategic position in the Swiss political system (positional approach). Finally, we checked during the 
first interviews conducted with the administrative actors responsible for the decision-making process that no powerful actor was missing (reputational approach). The resulting list comprises 38 actors for the first agreement and 44 actors for the second.

Based on these lists, we then selected the actors that we interviewed. To that end, we used the following criteria: Only actors that participated in at least one venue in addition to the very open consultation procedure were interviewed. ${ }^{5}$ This left us with 29 actors $(76 \%)$ for the first decision-making process and $26(59 \%)$ for the second. For reasons of comparability, we focus here on the 22 actors that were interviewed both times.

The dependent variable of our analysis is the collaboration network among actors. Based on the complete list of all actors participating in the respective decision-making process (and not only the list of interview partners), interview partners were asked to identify those actors with whom they had collaborated intensely, i.e. with whom they had frequent contact without necessarily agreeing on the substantive policy issue at stake. This results in a matrix containing directed collaboration links. Directed links are given when a link from actor i to actor $\mathrm{j}$ is not automatically reciprocated from actor $\mathrm{j}$ to actor $\mathrm{i}$.

Additional variables also stem from the interviews and are included as controls. The first is a measure of actors' reputational power. Again, from the complete list of actors, our interview partners were asked to mention the domestic actors that, in their view, had been "very influential" in the decision-making process regarding the agreement on the free movement of persons. Based on these answers, we calculate the reputational power score of each actor, which corresponds to the mean of the total judgments from all interview partners. Second, we also derive two measures of homophily from our interview data. On the one hand, according to the social network literature, two actors that share some sort of attribute are likely to develop ties (see e.g. Goodreau et al. 2009). Accordingly, we categorize actors according to their type, i.e. state actors, political parties, interest groups, and a residual category of a few other actors. On the other hand, the Advocacy Coalition Framework (ACF, Sabatier 1987, 
Sabatier and Weible 2007) suggests that actors sharing preferences with respect to a policy proposal are likely to collaborate. We therefore include a measure of convergence/divergence of preferences in our model. Based on the same list of actors participating in the decisionmaking process, we asked interview partners to mention the actors with whom they agreed or disagreed about the policy. These directed ties inform us about the perceived convergence or divergence of preferences.

Further, to test our hypotheses concerning the state's collaboration efforts, we created a group including state actors $^{6}$, a group with conservative Right-wing actors, namely the Swiss People's Party (SVP), two small extreme Right parties as well as the Action for an Independent and Neutral Switzerland (AUNS), and a group comprising the two Left-wing parties (the Social Democrats and the Greens) and the two major trade unions (Federation of Trade Unions and Travail Suisse).

\section{Method: Stochastic Actor-Oriented Models for network dynamics}

Stochastic actor-oriented models for network dynamics (SAOM) allow us to study tendencies in the network as opposed to a situation where ties would be sent and received at random. Strong tendencies, as formulated in our hypotheses, represent significant effects in the model, i.e. constellations in the collaboration network that cannot be due to random processes of tie formation.

Statistical analysis of network data is complicated by the fact that network ties cannot be assumed to be independent from each other (see e.g. Cramner et al. 2012). ${ }^{7}$ Therefore, SAOM model network dynamics operate in part endogenously, as a function of the current network structure (network effects), and in part exogenously, as a function of both the actors' characteristics (actors' covariates) and the characteristics of pairs of actors (dyadic covariates). They combine continuous time Markov analysis and random utility models (see Van den Bunt and Groenewegen 2007, Snijders et al. 2010). The models describe the 
evolution of a social network over time as a result of the rational actions of individual actors in the network (Van den Bunt et al. 1999: 171). SAOM deconstruct network evolution into its smallest constituents. The models assume that between the observations, the network is modified by a certain number of sequential steps, in which an actor creates one new tie each, terminates one existing tie, or does nothing at all. The probability of such a change depends on actors' preferences. It is assumed that actors try to maximize their expected utility by initiating or dissolving a tie. Actors' preferences are represented by the objective function. This function is the core of the actor-based model and determines the change according to the actors' preferences, constraints, and perceptions of their network environment. The objective function thus measures how attractive various different tie changes are for an actor, given the structure of the network and specific attributes of actors in the network (Snijders et al. 2010: 52).

As in generalized linear statistical models, the objective function is assumed to be a linear combination of a set of components called effects (Snijders et al. 2010: 47). The effects of parameters can be tested by referring to the t-ratio (Snijders et al. 2010: 50). Since these models are too complex for the application of classical maximum likelihood estimation procedures and testing methods, estimation is based on the method of moments and Monte Carlo computer simulation to approximate the expected values of the statistics (Van den Bunt et al. 1999).

\section{The model}

Directed collaboration ties between actors allow us to study which actor initiates cooperation with another actor. In order to explain these directed collaboration ties, the model comprises a series of exogenous variables based on the directed collaboration network. At the actor level, our model includes variables measuring incoming and outgoing collaboration ties of state 
actors, the conservative Right and the Left. In further models, we measure directed dyadic effects between state actors and the conservative Right and the Left, respectively.

A set of endogenous network parameters is included as a control: outdegree, reciprocity, and two triadic closure effects (transitive triplets and number of actors at distance two). These parameters serve to control for endogenous network evolution mechanisms, i.e. for the changes in the collaboration network that are a function of the current network structure. They must be controlled for before any further inferences about the effects of the other parameters' effects can be made (Snijders et al. 2010). The model further includes three additional variables controlling for exogenous tendencies, namely preference and actor type homophily (i.e. actors with similar preferences or of the same type), and actors' reputational power. ${ }^{8}$

\section{ANALYSIS AND DISCUSSION}

The models are estimated with the SIENA 4.0 package in R (Ripley and Boitmanis 2010, Ripley et al. 2011). ${ }^{9}$ Model coefficients appear in table 1 , whereas descriptive statistics on actors' in- and outgoing collaboration ties as well as their reputational power are presented in table 2. Table 2 does not allow us to test our hypotheses, but it provides information that helps us to interpret and discuss the results of our estimations.

\section{--- Table 1 about here ---}

Model 1 includes only network structure effects to control for endogenous network processes of tie formation. The significant but negative outdegree parameter indicates that over the two periods, actors had a low propensity for creating (random) ties to other actors. The significant and positive reciprocity parameter indicates that actors have a tendency to reciprocate collaborative ties, which means that if actor $\mathrm{i}$ indicates collaboration with actor $\mathrm{j}$, then actor $\mathrm{j}$ is likely to confirm this collaboration. Transitive triplets indicate the actors' tendency to create 
collaborative ties to actors they are already indirectly linked to (Burt 2001). The number of actors at distance two takes into account indirect connections between actors: the fewer the indirect connections between actors, the stronger the tendency towards network closure. Both parameters are significant and indicate network closure. Note, however, that both are no longer significant in some of the more complex models. ${ }^{10}$

\section{--- Table 2 about here ---}

In model 2, we introduce a first set of parameters that allows us to test hypothesis 1 . The significant and positive coefficient of the "state outgoing" variable shows that state actors have a stronger tendency than non-state actors to seek out collaboration with other actors. This result is in line with the argument that while state executives are especially powerful in Europeanized processes, they are nonetheless dependent on support from non-state actors and, therefore, do their best to collaborate with them.

A more detailed observation of the collaboration ties of state actors based on simple descriptive indicators (table 2) shows that the Integration Office and the State Secretary for Economy (Seco) were especially active during both decision-making processes. The Integration Office is the main administrative agency responsible for Switzerland's policy towards the EU. The Seco, for its part, had the important role of leading the negotiations between the social partners on the so-called "flanking measures" against social and wage dumping. Other administrative units (the Federal Migration Office, the Department of Foreign Affairs, and the Swiss Mission at the EU in Brussels) drastically increased their collaboration efforts between the first and the second treaty. For example, while the Department of Foreign Affairs only collaborated with other state actors in the first period, it tried to establish additional contacts with the most important political parties in the second period. ${ }^{11}$ Similarly, the Swiss Mission in Brussels, which was only in contact with the major trade union and the 
major peak economic association during the first decision-making process, sought collaboration with all potential veto-players during the second.

By contrast, according to our results, state executives do not have a tendency to attract collaboration ties. As indicated by the non-significant "state incoming" variable, state actors are not attracting significantly more collaboration ties than other actors. This lends further support for our argument that state executives are not passively lobbied, but actively search for collaboration in Europeanized policy domains. ${ }^{12}$

Hypothesis 2 states that in order to get the necessary domestic support for the international treaty, state executives make a specific effort to develop collaborations with potential vetoplayers from both the conservative Right and the Left. This was all the more important since both sides publicly expressed their concerns and threatened to oppose the treaty by referendum very early in the decision-making process.

The two variables, "state towards Left" and "state towards conservative Right," in model 3 explicitly take into account only collaboration ties offered from state actors to each of these potential veto players. Results show that state actors have a strong tendency to collaborate with both the Left and the conservative Right. In both decision-making processes, the referendum threat of the Left was highly credible (Fischer et al. 2002, Afonso et al. 2009). State executives were well aware that the treaty would probably not be supported in parliament and even less so in a popular vote if both the Left and the conservative Right opposed. To reduce the risk of opposition from the Left, the Swiss government started to negotiate with the social partners (trade unions and employers' associations) on the flanking measures as early as the international talks (Fischer 2002, Afonso 2010, Afonso and Papadopoulos 2013). The government's accommodating strategy towards the Left was eventually successful, as unions and the major Left-wing parties ended up supporting the treaty. 
Results of the stochastic actor-based model indicate that state executives also developed a proactive, inclusive strategy towards the other potential veto-players from the conservative Right. This strategy did not prove successful, as it did not prevent the conservative Right from launching a referendum. To be sure, given that the latter tends to oppose any form of Switzerland's integration into the EU, there was little that state executives could have done to overcome the opposition from the conservative Right. Once an agreement was found with the Left, the threat of a ratification failure was, however, considerably reduced. Facing only the opposition from the conservative Right, the Swiss government could take the risk of a popular vote. The risk paid off twice, as both agreements were eventually accepted by the people.

Model 4 is not of crucial importance for testing our hypotheses, but it provides additional insight into the collaboration structure. It includes parameters for incoming and outgoing ties of both sets of potential veto-players. Unlike model 3, this model does not specify where the collaboration tie comes from, nor where it goes to. First, both respective "outgoing" variables are not significant, as there is no evidence that any of the potential veto-players actively sought collaboration with other actors in the network. More importantly, the "incoming" variables regarding these two groups of actors demonstrate that only actors from the conservative Right, not the Left, were strongly targeted as collaboration partners by other actors in the policy network. As far as Left-wing actors are concerned, this means that only state executives (model 3), but no other actors attempted to integrate them. The situation is different with respect to the conservative Right: in addition to the collaboration attempts coming from state actors (controlled for by the "state outgoing" parameter), there is also a strong tendency of other actors in the network to initiate collaboration with the conservative Right. ${ }^{13}$

Models 2 to 4 control for other endogenous and exogenous factors that might affect collaboration. Most importantly, powerful actors are more likely to be the targets of collaboration attempts by other actors, but they do not have a strong tendency to initiate 
collaboration. As we can observe from Table 2, the four governing parties (the Social Democrats, the Swiss People's Party, the Radical Democrats, and the Christian Democrats), along with the social partners (trade unions and employers' associations) comprise the most powerful actors in this policy domain. The governing parties were already integrated into the domestic talks before the negotiations between Switzerland and the EU began (e.g., through the consultation of the parliamentary committees). Similarly, the Swiss government negotiated intensively with the social partners, who are important stakeholders on the issue of the free movement of persons. Further, preference and actor type homophily also matter to some extent: actors with similar preferences or who belong to the same type tend to collaborate, but effects are weak.

\section{CONCLUSIONS}

This paper looks at the factors that affect the collaboration network in a Europeanized policy domain. We argue that while Europeanized processes strengthen state actors, the latter are still very dependent on domestic, non-state actors, and most especially on potential veto-players. They therefore need to integrate these potential veto-players into the decision-making process in order to gain domestic support for their foreign policy proposals.

To test how such collaboration efforts affect the network in this rather new policy domain, we rely on a stochastic actor-oriented model for network dynamics. We apply this model to the collaboration network regarding the two bilateral agreements on the free movement of persons that Switzerland negotiated with the EU. The model enables us to include endogenous as well as exogenous network effects and, therefore, to carry out a detailed and dynamic investigation of a complex network configuration.

Our two hypotheses were largely confirmed by the analysis. First and foremost, our results show that state executives are not passively lobbied, i.e. approached for collaboration, but that they themselves actively attempt to collaborate with other actors. In order to make sure that an 
international treaty will be accepted at the domestic level, i.e. that the parliament will ratify it and that the referendum will either not be called or will result in a positive outcome, state executives are proactive and carefully integrate domestic non-state actors into the decisionmaking process.

Second, and more specifically, we find that especially euro-skeptical actors, namely conservative Right-wing parties, and trade unions and Left-wing parties, tend to be the targets of increased collaboration efforts by state actors. On the one hand, we witness strong integration efforts from state actors to the Left: the pro-active strategy of state executives towards the Left turned out to be highly successful. Indeed, as a result of its integration in the decision-making process and of the adoption of flanking measures, the Left abstained from launching a referendum. This also means that the strategy of the Left was equally successful. By threatening early to veto the treaty in the ratification phase unless they got flanking measures to protect the Swiss workforce against social and wage dumping, Left-wing actors forced the Swiss government and its state administration to react. As a consequence, they were ultimately able to get most of their demands satisfied.

Conservative Right-wing parties oppose European integration in general, and they had already demonstrated that their "referendum threat" was credible. Therefore, state executives - and additional actors - made significant efforts to integrate the conservative Right into the policy network. However, these integration efforts did not prevent conservative right parties and organizations from calling a referendum, but they were eventually defeated in the popular vote.

Results from this analysis potentially have implications for future research on Europeanization and policy networks. They raise the question of whether the integration mechanisms at work in this particular case are also significant for other Europeanized or internationalized processes in Switzerland and in other European countries. First, while the opposition from the conservative Right is most likely similar for every Europeanized domain, 
the one from the Left might be more specific to the measure of economic liberalization. However, given that European integration mainly means negative integration, a similar attitude from Leftist parties and trade unions is likely in other Europeanized policy domains. It would thus be worthwhile to look at the strategy of state executives towards potential veto players from both the Left and the conservative Right in additional cases. Second, it is true that the incentive to look for across-the-board support is, presumably, especially strong in Switzerland owing to the existence of the "referendum threat." However, the constitutional provision requiring a qualified majority in national parliament for treaty revision existing in some EU countries also forces state executives to gain broad domestic support. In that sense, the arguments developed in this paper open up promising avenues for further research in Switzerland as well as in EU countries.

Biographical notes: Manuel Fischer is a post-doctoral researcher in Political Science at the Swiss Federal Institute of Aquatic Science and Technology (Eawag). Pascal Sciarini is a Professor for Swiss and Comparative Politics at the University of Geneva, Switzerland.

Address for correspondence: Manuel Fischer, Environmental Social Sciences, Eawag, Überlandstrasse 133, CH-8600 Dübendorf, Switzerland. Email: $\underline{\text { manuel.fischer@eawag.ch / }}$ Pascal Sciarini, Department of political science and international relations, University of Geneva, 40 boulevard du Pont d'Arve, CH-1211 Genève 4, Switzerland. Email : pascal.sciarini@unige.ch.

\section{ACKNOWLEDGEMENTS}

The authors wish to thank Sandrine Bossy, David Keller, Guenda Malinverni, and Denise Traber who contributed to the data gathering. This article is part of a wider research project sponsored by the Swiss Science Foundation (Grant No. 100012-113964). Thanks for their 


\section{helpful comments also go to Marie-Christine Fontana, Johan Koskinen, Dirk Lehmkuhl,}

Frédéric Varone, and to the editor and two anonymous reviewers of this journal.

1 Whether collaboration ultimately leads to a compromise or not is another issue, which is not relevant for the sort of "neutral" collaboration we are investigating in this study.

2 This does not mean that state actors are more powerful than the most important domestic, non-state actors, but merely that state actors are more powerful in Europeanized processes than in domestic processes. As Table 2 shows, state actors are not more powerful than other types of actors in the case under study.

3 Formal consultation mechanisms are official stages of the decision-making process and grant access to either selected actors (in so-called working groups or experts' commissions) or to all interested actors (in a consultation procedure). Informal consultation mechanisms consist of unofficial, ad-hoc, or personal contact between representatives of the state administration and stakeholders.

4 Taken together, Left-wing and conservative Right-wing parties hold a majority of seats in the National Council, the lower Chamber of Swiss Parliament. Second, by collecting 50'000 signatures in 100 days, any group can oppose a legislative act voted on by the Swiss parliament and call for a popular vote, which is then decisive. The optional referendum applies to important international treaties, such as the bilateral treaties with the EU.

5 The consultation procedure is an important venue in Swiss decision-.making processes, as it allows every interested actor to express its opinion on the project before it is sent to parliament. However, because the consultation procedure is open to every interested actor, some very unimportant actors do also participate in this venue. We therefore decided to focus our interviews on actors that participated in at least one other venue of the decision-making process in addition to the consultation procedure. Results regarding reputational power confirmed that we did interview the most important actors.

6 The group of state actors includes all administrative agencies responsible for foreign and migration policy. Note that we did not code the Federal Office of Justice as belonging to the group of state actors, since this office did not play a political role during the decision-making process; it was only asked to control judicial aspects of the agreement.

7 This is a common assumption on which statistical models for non-network data are usually based. 
8 Note that the actor type homophily effect includes a state actor homophily effect. This is important as it ensures that the "state outgoing" and "state incoming" effects are not influenced by collaboration ties among state actors.

9 Results can be accepted if the t-ratios for model convergence are less than 0.1 , which is the case for all models. Further, the Jaccard index, which expresses the amount of change between two waves, should preferably be higher than 0.3 (Snijders et al. 2010: 49), which is the case here (0.52).

10 The rate parameter $\rho$ in the first row represents the expected average number of opportunities for relational changes per actor from $t_{x}$ to $t_{x+1}$.

11 The exact links cannot be grasped from table 2, but only from the original matrices.

12 This pattern is less clearly observable from the simple descriptive statistics in table 2, which do not control for other effects.

13 Additional tests not reported here show that Center-Right parties and employers' associations have no tendency to attempt to collaborate with the conservative Right. 


\section{REFERENCES}

Afonso, A. (2010) 'Policy concertation, Europeanization and new political cleavages: The case of Switzerland', European Journal of Industrial Relations 16 (1): 57-72.

Afonso, A. and Papadopoulos, Y. (2013) 'Europeanization or Party Politics? Explaining Government Choice for Corporatist Concertation', Governance 26 (1): 5-29.

Afonso, A., Fontana, M.-C. and Papadopoulos, Y. (2009) 'Does Europeanisation weaken the Left? Changing coalitions and veto power in Swiss decision-making processes', Policy \& Politics 38 (4): 565-82.

Berardo, R. and Scholz, J. T. (2010) 'Self-Organizing Policy Networks: Risk, Partner Selection and Cooperation in Estuaries', American Journal of Political Science 54 (3): 632-49.

Börzel, T. A. (1998) 'Organizing Babylon - On the Different Conceptions of Policy Networks', Public Administration 76: 253-73.

Burt, R. S. (2001) 'Structural Holes Versus Network Closure as Social Capital', in N. Lin, K. S. Cook and R. S. Burt (eds.), Social Capital: Theory and Research, New York: Aldine de Gruyter, pp. 31-56.

Cramner, S. J., Desmarais, B. A. and Menninga, E. J. (2012) 'Complex Dependencies in the Alliance Network', Conflict Management and Peace Science 29 (3): 279-313.

Dupont, C. and Sciarini, P. (2006) 'Back to the future: the first round of bilateral talks with the EU', in C. Church (ed.), Switzerland and the European Union: A Close, Contradictory and Misunderstood Relationship, London: Routledge, pp. 202-14.

Dupont, C., Sciarini, P. and Eggli, C. (2001) 'Entre cohérence et efficacité: la Suisse dans les négociations bilatérales avec l'Union Européenne', Swiss Political Science Review 7 (4): 5-37. 
Fischer, A. (2002) 'Wirtschaftsbranche, Gewerkschaftsstärke und Interessengegensätze der Arbeitgeber: Der Fall der flankierenden Massnahmen zur Personenfreizügigkeit', Swiss Political Science Review 8 (3/4): 85-100.

. (2003) 'Vetospieler und die Durchsetzbarkeit von Side-Payments', Swiss Political Science Review 9 (2): 27-58.

—. (2005) Die Auswirkung der Internationalisierung und Europäisierung auf Schweizer Entscheidungsprozesse. Edited by K. Armingeon, P. Knoepfel, I. Papadopoulos and F. Varone, Analyse des politiques publiques / Politikanalyse, Zürich/Chur: Verlag Rüegger.

Fischer, A., Nicolet, S. and Sciarini, P. (2002) 'Europeanisation of Non EU-Countries: The Case of Swiss Immigration Policy Towards the EU', West European Politics 25 (3): 143-70.

Fischer, M. (2012) Entscheidungsstrukturen in der Schweizer Politik zu Beginn des 21. Jahrhunderts. Zürich/Chur: Verlag Rüegger.

Fischer, M., Ingold, K., Sciarini, P. and Varone, F. (2012) 'Impacts of Market Liberalization on Regulatory Network: A Longitudinal Analysis of the Swiss Telecommunications Sector', The Policy Studies Journal 40 (3): 435-57.

Goetz, K. H. and Meyer-Sahling, J.-H. (2008) 'The Europeanisation of national political systems: Parliaments and executives', Living Reviews on European Governance 3 (2).

Goodreau, S. M., Kitts, J. A. and Morris, M. (2009) 'Birds of a feather, or friend of a friend? Using exponential random graph models to investigate adolescent social networks', Demography 46 (1): 103-25.

Haverland, M. (2000) 'National adaptation to European integration: the importance of institutional veto points', Journal of Public Policy 20 (1): 83-103.

Henry, A. D. (2011) 'Ideology, Power, and the Structure of Policy Networks', Policy Studies Journal 39 (3): 361-83. 
Hooghe, L., Marks, G. and Wilson, C. J. (2002) 'Does Left/Right Structure Party Positions on European Integration?', Comparative Political Studies 35: 965-89.

Immergut, E. M. (1990) 'Institutions, VetoInstitutions, Veto Points and Policy Results: A Comparative Analysis of Health Care', Journal of Public Policy 10 (4): 391-416.

Katzenstein, P. (1985) Small States in World Markets, Cornell: Cornell University Press.

Knoke, D. (1993) 'Networks of Elite Structure and Decision Making', Sociological Methods \& Research 22 (1): 22-45.

Knoke, D., Pappi, F. U., Broadbent, J. and Tsujinaka, Y. (1996) Comparing Policy Networks Labor Politics in the U.S., Germany, and Japan, Cambridge: Cambridge University Press.

Kriesi, H., Adam, S. and Jochum, M. (2006a) 'Comparative analysis of policy networks in Western Europe', Journal of European Public Policy 13 (3): 341-61.

Kriesi, H., Longchamp, C., Sciarini, P. and Passy, F. (1993) Analyse-VOX de la votation fédérale du 6 décembre 1992 sur l'EEE, Genève/Zürich: Département de Science Politique/GfS-Forschungsinstitut.

Kriesi, H., Grande, E., Lachat, R., Dolezal, M., Bornschier, S. and Frey, T. (2006b) 'Globalization and the transformation of the national political space: Six European countries compared', European Journal of Political Research 45: 921-56.

Lubell, M., Scholz, J., Berardo, R. and Robins, G. (2012) 'Testing Policy Theory with Statistical Models of Networks', The Policy Studies Journal 40 (3): 351-74.

Mach, A., Häusermann, S. and Papadopoulos, Y. (2003) 'Economic regulatory reforms in Switzerland: adjustments without European integration, or how rigidities become flexible', Journal of European Public Policy 10 (2): 301-18.

Moravcsik, A. (1998) The Choice for Europe: Social Purpose and State Power from Messina to Maastricht, Ithaca, New York: Cornell University Press. 
Putnam, R. D. (1988) 'Diplomacy and domestic politics: the logic of two level games', International Organization 42 (3): 427-60.

Ripley, R. M. and Boitmanis, K. RSiena (http://www.stats.ox.ac.uk/ snijders/siena/). 2010.

Ripley, R. M., Snijders, T. A. B. and Lopez, P. P. (2011) Manual for RSiena Oxford: University of Oxford, Nuffield College.

Sabatier, P. A. (1987) 'Knowledge, Policy-Oriented Learning, and Policy Change: An Advocacy Coalition Framework', Science Communication 8: 649-92.

Sabatier, P. A. and Weible, C. M. (2007) 'The Advocacy Coalition Framework', in P. A. Sabatier (ed.), Theories of the Policy Process, Boulder, Colorado: Westview Press, pp.

Scholz, J. T., Berardo, R. and Kile, B. (2008) 'Do Networks Solve Collective Action Problems? Credibility, Search, and Collaboration', The Journal of Politics 70 (2): 393406.

Sciarini, P. and Listhaug, O. (1997) 'Single Cases or a Unique Pair: The Swiss and Norwegian No to Europe', Journal of Common Market Studies 35 (3): 407-38.

Sciarini, P., Fischer, A. and Nicolet, S. (2004) 'How Europe hits home: evidence from the Swiss case', Journal of European Public Policy 11 (3): 353-78.

Snijders, T. A. B., Van den Bunt, G. G. and Steglich, C. E. G. (2010) 'Introduction to stochastic actor-based models for network dynamics', Social Networks 32 (1): 44-60.

Van den Bunt, G. G., Van Duijn, M. A. J. and Snijders, T. A. B. (1999) 'Friendship Networks Through Time: An Actor-Oriented Dynamic Statistical Network Model', Computational \& Mathematical Organization Theory 5 (2): 167-92.

Van den Bunt, G. and Groenewegen, P. (2007) 'An Actor-Oriented Dynamic Network Approach: The Case of Interorganizational Network Evolution', Organizational Research Methods 10 (3): 463-82.

Weible, C. M. and Sabatier, P. A. (2005) 'Comparing Policy Networks: Marine Protected Areas in California', The Policy Studies Journal 33 (2): 181-201. 
Table 1: SIENA model estimates

\begin{tabular}{|c|c|c|c|c|}
\hline & Model 1 & Model 2 & Model 3 & Model 4 \\
\hline Rate parameter $\mathrm{p} t 1-\mathrm{t} 2$ & $\begin{array}{c}11.450 * * * \\
(1.926)\end{array}$ & $\begin{array}{c}10.527^{* * *} \\
(1.451)\end{array}$ & $\begin{array}{c}11.428^{* * *} \\
(1.783)\end{array}$ & $\begin{array}{c}10.175^{* * *} \\
(1.388)\end{array}$ \\
\hline \multicolumn{5}{|l|}{ Exogenous effects: } \\
\hline State outgoing & & $\begin{array}{c}1.865^{* * *} \\
(0.743)\end{array}$ & & $\begin{array}{c}2.279 * * \\
(0.928)\end{array}$ \\
\hline State incoming & & $\begin{array}{c}0.358 \\
(0.310)\end{array}$ & & $\begin{array}{l}0.640 * \\
(0.380)\end{array}$ \\
\hline Left outgoing & & & & $\begin{array}{c}0.441 \\
(0.678)\end{array}$ \\
\hline Left incoming & & & & $\begin{array}{c}-0.619 \\
(0.777)\end{array}$ \\
\hline Conservative Right outgoing & & & & $\begin{array}{c}0.778 \\
(0.596)\end{array}$ \\
\hline Conservative Right incoming & & & & $\begin{array}{c}1.793 * * * \\
(0.673)\end{array}$ \\
\hline State towards Left & & & $\begin{array}{c}0.977^{* *} \\
(0.466)\end{array}$ & \\
\hline State towards Conserv. Right & & & $\begin{array}{c}0.971 * * \\
(0.473)\end{array}$ & \\
\hline Power outgoing & & $\begin{array}{l}-0.007 \\
(0.005)\end{array}$ & $\begin{array}{c}-0.008 * * \\
(0.004)\end{array}$ & $\begin{array}{c}-0.004 \\
(0.006)\end{array}$ \\
\hline Power incoming & & $\begin{array}{c}0.015^{* * *} \\
(0.006)\end{array}$ & $\begin{array}{c}0.010 * * \\
(0.004)\end{array}$ & $\begin{array}{c}0.025 * * * \\
(0.009)\end{array}$ \\
\hline Preference homophily & & $\begin{array}{l}0.467^{*} \\
(0.257)\end{array}$ & $\begin{array}{c}0.659 * * * \\
(0.241)\end{array}$ & $\begin{array}{c}0.116 \\
(0.364)\end{array}$ \\
\hline Actor type homophily & & $\begin{array}{c}0.460 * * \\
(0.228)\end{array}$ & $\begin{array}{c}0.489 * * \\
(0.214)\end{array}$ & $\begin{array}{c}0.267 \\
(0.272)\end{array}$ \\
\hline Left homophily & & & & $\begin{array}{c}0.161 \\
(0.696)\end{array}$ \\
\hline Conservative Right homophily & & & & $\begin{array}{c}2.189 * * * \\
(0.664)\end{array}$ \\
\hline
\end{tabular}

Network structure effects:

$\begin{array}{lcccc}\text { Outdegree } & -1.376^{* * *} & -1.481^{* * *} & -1.748^{* * *} & -3.065^{* * *} \\ & (0.165) & (0.288) & (0.254) & (0.838) \\ \text { Reciprocity } & 0.898^{* * *} & 1.191^{* * *} & 1.048^{* * *} & 1.096^{* * *} \\ & (0.204) & (0.293) & (0.238) & (0.336) \\ \text { Transitive triplets } & 0.095^{* * *} & 0.076^{* *} & 0.113^{* * *} & 0.066 \\ & (0.020) & (0.035) & (0.033) & (0.042) \\ \text { Number of actors at dist. two } & -0.196^{* *} & -0.301 & -0.129 & -0.319 \\ & (0.094) & (0.225) & (0.162) & (0.387)\end{array}$

Note: Levels of significance: ${ }^{*}=0.05 ;^{* *}=0.01 ;^{* * *}=0.001$.

The variables in italic are included as controls. 
Table 2: Descriptives: Actors' reputational power and outgoing/incoming collaboration ties

\begin{tabular}{|c|c|c|c|c|c|c|c|}
\hline \multirow[b]{2}{*}{ Type } & \multirow[b]{2}{*}{ Actor } & \multicolumn{3}{|c|}{ 1st treaty } & \multicolumn{3}{|c|}{ 2nd treaty } \\
\hline & & Power & Outgoing & Incoming & Power & Outgoing & Incoming \\
\hline \multirow{7}{*}{$\underset{\stackrel{9}{\pi}}{\stackrel{ \pm}{\sim}}$} & Integration Office & 0.41 & 17 & 14 & 0.56 & 17 & 15 \\
\hline & Swiss Mission at EU & 0.25 & 6 & 8 & 0.29 & 17 & 7 \\
\hline & State Secr. for Economy & 0.7 & 16 & 19 & 0.73 & 17 & 16 \\
\hline & Dep. of Foreign Affairs & 0.22 & 2 & 6 & 0.62 & 9 & 9 \\
\hline & Fed. Migration Office & 0.32 & 4 & 9 & 0.31 & 17 & 11 \\
\hline & Fed. Office for Justice & 0.14 & 6 & 2 & 0.1 & 4 & 3 \\
\hline & Average & 0.34 & 8.5 & 9.67 & 0.44 & 13.5 & 10.17 \\
\hline \multirow{5}{*}{$\stackrel{\square}{\square}$} & Federation of Trade Unions & 0.84 & 9 & 10 & 0.8 & 8 & 10 \\
\hline & Travail.CH & 0.38 & 10 & 10 & 0.5 & 12 & 8 \\
\hline & Social Democratic Party & 0.75 & 12 & 9 & 0.84 & 8 & 13 \\
\hline & Green Party & 0.03 & 5 & 3 & 0.22 & 5 & 4 \\
\hline & Average & 0.5 & 9 & 8 & 0.59 & 8.25 & 8.75 \\
\hline \multirow{5}{*}{ 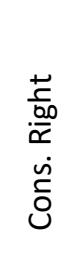 } & Swiss People's Party & 0.66 & 10 & 8 & 0.7 & 2 & 11 \\
\hline & Lega dei Ticinesi & 0.11 & 3 & 2 & 0.08 & 3 & 2 \\
\hline & Swiss Democrats & 0.05 & 0 & 2 & 0.16 & 3 & 3 \\
\hline & AUNS & 0.22 & 9 & 3 & 0.36 & 5 & 5 \\
\hline & Average & 0.26 & 5.5 & 3.75 & 0.33 & 3.25 & 5.25 \\
\hline \multirow{7}{*}{ 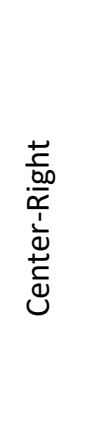 } & Employers' Association & 0.79 & 10 & 12 & 0.7 & 11 & 10 \\
\hline & Farmers' Association & 0.17 & 13 & 7 & 0.2 & 8 & 7 \\
\hline & $\begin{array}{c}\text { Small Businesses } \\
\text { Association }\end{array}$ & 0.62 & 11 & 13 & 0.54 & 8 & 11 \\
\hline & Christian Democrats & 0.61 & 11 & 11 & 0.74 & 14 & 14 \\
\hline & Economiesuisse & 0.5 & 7 & 10 & 0.9 & 10 & 13 \\
\hline & Radical Democrats & 0.71 & 8 & 13 & 0.8 & 8 & 14 \\
\hline & Average & 0.57 & 10 & 11 & 0.65 & 9.83 & 11.5 \\
\hline \multirow{3}{*}{$\begin{array}{l}\grave{\Phi} \\
\frac{1}{ \pm} \\
0\end{array}$} & VSAA & 0.09 & 5 & 2 & 0.12 & 2 & 4 \\
\hline & Cantonal Governments & 0.42 & 5 & 6 & 0.38 & 9 & 7 \\
\hline & Overall average & 0.41 & 8.14 & 8.14 & 0.48 & 8.95 & 8.95 \\
\hline
\end{tabular}

